\title{
Peningkatan Prestasi Belajar IPA Materi Berbagai Sumber Energi Melalui Media KABIB (Kartu Belajar Ajaib) Pada Siswa Kelas IV SDN 1 Karangan Kecamatan Karangan Kabupaten Trenggalek Semester I Tahun Pelajaran 2017/2018
}

\author{
Siti Muslikhah \\ Sekolah Dasar Negeri 1 Karangan, Trenggalek \\ Email: sdn1karangan@gmail.com
}

\begin{abstract}
Abstrak: Media pembelajaran adalah komponen penting untuk menentukan keaktifan dan keberhasilan suatu pembelajaran. Guru sebagai agen pembelajaran dituntut untuk selalu mengembangkan keprofesiannya, dengan cara menggunakan media pembelajaran yang sesuai dengan materi yang diajarkan. Penelitian ini menggunakan model ADDIE, model prosedural yang menunjukkan langkah-langkah dalam pengembangan. Langkah-langkah prosedural dari model ADDIE terdiri dari langkah analysis, design, development, implementation serta evaluation. KABIB digunakan sebagai media dalam penelitian ini, dengan tujuan (1) mengetahui kevalidan media KABIB untuk meningkatkan kemapuan memahami berbagai sumber energi kelas IV, (2) mengetahui keefektifan media KABIB untuk meningkatkan kemampuan memahami berbagai sumber energi

Tersedia Online di

http://journal.unublitar.ac.id/pendidi

kan/index.php/Riset_Konseptual

\begin{tabular}{l}
\hline Sejarah Artikel \\
\hline Diterima pada $: 26-10-2019$ \\
Disetujui pada : 26-10-2019 \\
Dipublikasikan pada : 31-10-2019
\end{tabular}

Kata Kunci:

Prestasi belajar, Media Pembelajaran, KABIB (Kartu Belajar Ajaib), Sumber Energi

DOI:

htt1/doi.org/10.28926/riset_konseptual.v3i4. 165

kelas IV. Manfaat penelitian ini bagi siswa yang menjadi subyek penelitian adalah meningkatnya prestasi belajar dalam materi Berbagai Sumber Energi. Manfaat bagi guru adalah meningkatan kemampuan guru dalam memilih media pembelajaran yang sesuai dengan materi ajar sehingga siswa menjadi aktif, kreatif, inovatif, efektif dan menyenangkan, Penelitihan ini adalah penelitian Tindakan (action research). Pembelajan IPA materi Berbagai Sumber Energi ini dirancang dalam dua siklus. Hasil penelitian: pada siklus I hasil pembelajaran peserta didik belum tuntas, siswa yang mencapai ketuntasan sebanyak 14 anak dengan prosentase $70 \%$. Pada Siklus II hasil pembelajaran peserta didik sudah mencapai ketuntasan, karena siswa yang telah tuntas sebanyak 17 anak dengan prosentase sebesar $85 \%$. Terjadi peningkatan nilai rata-rata dari 69,25 pada siklus I menjadi 80 pada siklus II. Hal ini berarti hasil belajar siswa meningkat 10,75. Kesimpulan penelitian ini adalah media KABIB dapat meningkatkan Prestasi Belajar IPA Materi Berbagai Sumber Energi Pada Siswa kelas IV semester II tahun pelajaran 2017-2018 di SDN 1 Karangan Kecamatan Karangan, Kabupaten Trenggalek.
\end{abstract}

\section{PENDAHULUAN}

Pelajaran IPA di kelas IV SDN 1 Karangan tak ubahnya mata pelajaran lain yang memiliki ciri khas ranah kompetensi yang cenderung pada pemahaman dan hafalan, sehingga penyampaian materi oleh guru condong menggunakan ceramah sebagai pilihan utama metode, yang disertai dengan tanya jawab. Pada kenyataannya guru masih kurang memanfaatkan bahan ajar dengan maksimal. Bahan ajar yang dimaksud adalah bahan ajar jenis media yang inovatif, sehingga guru hanya menggunakan buku teks dan media seadanya saja (Prawiradilaga, 2008). Selain itu karakteristik dari siswa juga berpengaruh, dimana siswa kurang minat pada materi pembelajaran khususnya 
materi sumber energi. Kurang minatnya siswa dipengaruhi oleh penggunaan media yang kurang optimal dan menarik (B. Uno, 2008). Maka dari itu, untuk mengatasi masalah tersebut dilakukan Research and Development penelitian pada kelas IV SDN 1 Karangan pada materi sumber energi. Hal ini terbukti masih rendahnya nilai mata pelajaran IPA, hasil evaluasi rata-rata 66 (55\%) dari KKM 70. ,

Berdasarkan probematika diatas, perlu adanya tindakan dan suatu pemikiran yang harus dilaksanakan oleh guru, agar konsep IPA yang dipelajari oleh siswa khususnya pada materi Sumber Energi siswa menjadi aktif, kreatif, efektif, menyenangkan dan tumbuh minat belajar pada dirinya, dengan harapan bahwa tujuan pembelajaran bisa dicapai dengan hasil yang memuaskan (Arikunto, 2011). Oleh sebab itu peneliti mencoba memperbaikinya melalui penggumaan Media KABIB (Kartu Belajar Ajaib) .Pembelajaran penggunaan Media KABIB yaitu model pembelajaran yang dirancang untuk memecahkan suatu materi pembelajaran melalui diskusi kelompok (Rusman, 2010). Sehingga nantinya akan memunculkan kompetensi siswa dalam memecahkan masalah/materi ajar melalui interaksi kelompok yang aktif dan inisiatif (Huda, 2011). Dalam hal ini, peneliti mengusulkan Penelitian Tindakan Kelas untuk guna meningkatkan prestasi belajar IPA materi berbagai sumber energi melalui media KABIB (kartu belajar ajaib) pada siswa kelas IV SDN 1 Karangan Kecamatan Karangan Kabupaten Trenggalek semester I tahun pelajaran 2017/2018. Penelitian ini disusun untuk menghasilkan produk penggunaan media visual dua dimensi berupa Kartu Belajar Ajaib (KABIB) untuk menunjang pembelajaran IPA materi berbagai sumber energi (Nana S., 2002). Tujuan penelitian ini antara lain: 1) Mendeskripsikan prosedur penggunaan media KABIB (Kartu Belajar Ajaib) untuk materi berbagai sumber energi siswa kelas IV SDN 1 Karangan tahun pelajaran 2017/2018; 2) Mendeskripsikan validitas produk penggunaan media KABIB (Kartu Belajar Ajaib) untuk materi berbagai sumber energi siswa kelas IV SDN 1 Karangan tahun pelajaran 2017/2018; 3) Mendeskripsikan efektifitas penggunaan media KABIB (Kartu Belajar Ajaib) untuk materi berbagai sumber energi siswa kelas IV SDN 1 Karangan tahun pelajaran 2017/2018.

Penelitian ini disusun memiliki manfaat yang positif bagi siswa, guru dan sekolah, antara lain: 1) manfaat bagi siswa adalah sebagai upaya meningkatkan prestasi belajar IPA Materi Berbagai Sumber Energi siswa kelas IV semester I tahun Pelajaran 2017/2018 di SDN 1 Karangan kecamatan Karangan Kabupaten Trenggalek; 2) bagi guru, dapat menjadikan proses belajar mengajar lebih aktif, kreatif, efektif serta dapat sebagai bahan pertimbangan para guru agar dapat menerapkan penggunaan media KABIB sebagai media pengembangan kegiatan pembelajaran; 3) bagi sekolah, pembelajaran penggunaan media KABIB menjadi masukan yang berharga tentang informasi media pembelajaran yang efektif sehingga mampu mencapai tujuan. (Moleong, 2002).

\section{METODE}

Penelitian Tindakan Kelas ini dilakukan di SD Negeri 1 Karangan tempat peneliti bertugas serta merupakan Penelitian Tindakan Kelas, karena permasalahan timbul didalam kelas dengan ditandai rendahnya tingkat kemampuan siswa dalam menerima pelajaran (Jauhan, 2011). Penelitian ini terdiri dari 2 Siklus, Siklus I dilaksanakan selama dua pertemuan yaitu pada tanggal 11 dan 12 September 2018, dengan materi Berbagai Sumber Energi, dan Siklus II dilaksanakan selama dua pertemuan yaitu pada tanggal 25 dan 26 September 2018, dengan materi Berbagai Macam Sumber Energi. Tiap siklus dilaksanakan dalam empat tahap, yaitu: (1) tahap perencanaan, (2) tahap pelaksanaan atau tindakan (3) tahap pengamatan atau observasi dan (4) tahap refleksi (Made Wena, 2009).

1. Perencanaan

Pada tahap ini peneliti melakukan persiapan perangkat yang akan digunakan selama kegiatan penelitian yang meliputi menyusun silabus, menyusun rencana 
pelaksanaan pembelajaran, menyusun lembar diskusi, menyusun instrument penilaian (soal tes tulis, kunci jawaban disertai penyekoran), lembar observasi kegiatan siswa dan lembar observasi kegiatan guru.

2. Pelaksanaan

Tahap ini merupakan pelaksanaan dari semua rencana yang sudah dibuat yaitu model pembelajaran Penggunaan Media KABIB dengan langkah-langkah sebagai berikut:

a. Menyiapkan alat dan bahan yang akan digunakan dalam proses pembelajaran kelompok kecil.

b. Memilih seluruh siswa kelas IV SDN 1 Karangan yang berjumlah 20 siswa.

c. Memulai pembelajaran dengan menjelaskan materi secara singkat mengenai materi berbagai sumber energi yang akan dipelajari.

d. Memperkenalkan media KABIB sebagai alat bantu penguatan materi yang telah dipelajari siswa.

e. Mengaitkan materi berbagai sumber energi dengan menggunakan media KABIB.

f. Setelah siswa mendapatkan penguatan pemahaman materi dengan menggunakan media KABIB, melakukan tanya jawab dengan siswa.

g. Siswa diminta untuk mengerjakan soal post test untuk mengetahui kemampuan siswa.

h. Mengevaluasi hasil pekerjaan siswa setelah penggunaan media KABIB.

3. Pengamatan

Kegiatan observasi dilakukan bersamaan dengan pelaksanaan tindakan (Slavin, 2010). Pada kegiatan ini pengamatan dilakukan oleh seorang guru yang bertugas sebagai kolaborator yang mengobservasi kegiatan guru saat KBM dan juga mengobservasi anak pada saat pembelajaran.

4. Refleksi

Pada tahap ini merupakan tahap untuk memproses data yang telah didapat pada saat dilakukan pengamatan. Tindakan selanjutnya yaitu; 1) guru menganalisis data yang terkumpul yaitu data observasi guru saat KBM, observasi siswa pada saat KBM atau saat diskusi dan hasil evaluasi; 2) bila hasil refleksi menunjukkan belum tercapainya indikator yang telah ditetapkan, yaitu75\% siswa telah memperoleh nilai sama dengan atau lebih besar dari KKM 70 penelitian dilanjutkan ke siklus berikutnya, 3) guru mencari alternatif pemecahan untuk siklus berikutnya.

\section{HASIL dan PEMBAHASAN}

Kegiatan pembelajaran IPA di kelas IV semester 1 tentang Berbagai Sumber Energi tidak berbeda jauh dengan kegiatan pembelajaran bidang studi lain. Guru selalu menggunakan metode ceramah yang dilanjutkan dengan tanya-jawab. Proses pembelajaran tersebut berjalan lancar seakan tidak ada kendala, terbukti ada beberapa siswa yang bertanya tentang materi yang dipahami. Kemudian dengan bimbingan guru, siswa membuat kesimpulan tentang berbagai sumber energi. Namun setelah peneliti melakukan evaluasi diakhir proses pembelajaran ternyata dari 20 siswa yang tuntas hanya 11 siswa atau 55\% dengan nilai rata-rata 66. Menurut peneliti penyebab utama kekurang berhasilan ini adalah kurang tepatnya guru dalam menentukan metode pembelajaran dan kurangnya guru dalam pengelolaan kelas. Hal ini tampak disaat guru menjelaskan materi masih ada anak yang bicara dengan temannya dan bermain sendiri serta saat guru memberi kesempatan untuk bertanya tentang materi yang belum dipahami kesempatan ini cuma dimanfaatkan oleh beberapa anak saja, kebanyakan yang lainnya hanya diam.Menyadari akan kelemahan dan ketidakberhasilan itu, peneliti mencoba untuk mencari model pembelajaran Jigsaw yang mengaktifkan siswa dan memberi tantangan kepada siswa untuk lebih aktif, kreatif, efektif dalam suasana pembelajaran yang menyenangkan sehingga mampu meningkatkan prestasi belajar siswa. 
Siklus 1

a. Perencanaan:

Perencanaan Penelitian Tindakan Kelas siklus 1 ini dilaksanakan di SDN 1 Karangan selama dua siklus yaitu pada tanggal 11 dan12 September 2018 dengan Kompetensi Dasar Mengidentifikasi berbagai sumber energi,perubahan bentuk energi dan sumber energi alternatif dalam kehidupan sehari-hari. Pada tahap ini kegiatan yang dilakukan meliputi : persiapan silabus, rencana pelaksanaan pembelajaran (RPP) (lampiran1), lembar kerja siswa (lampiran 2). Rencana Pelaksanaan Pembelajaran terkait dengan materi mengidentifikasi berbagai sumber energi dengan menggunakan media KABIB (Kartu Belajar Ajaib ).. Rencana Pelaksanaan Pembelajaran merupakan pedoman untuk melaksanakan proses pembelajaran di kelas. Oleh karena itu Rencana Pelaksanaan Pembelajaran harus menggambarkan proses pembelajaran secara rinci dan memuat pengalaman belajar yang harus dimiliki siswa setelah mengikuti proses pembelajaran.

\section{b. Pelaksanaan}

Pada tahap ini peneliti melaksanakan pembelajara berdasarkan rencana pelaksanaan pembelajaran yang sudah dibuat. Adapun langkah-langkah pada pelaksanaan ini adalah Pendahuluan (10 menit), kegiatan inti (45 menit) serta penutup (10 menit). Pendahuluan berisi kegiatan 1) guru mengucapkan salam dan meminta salah satu siswa untuk memimpin do'a; 2) guru mengabsen kehadiran siswa; 3) guru melakukan apersepsi dengan menyanyi lagu macam-macam energi dengan lirik lagu pelangi; 4) Guru menyampaikan tujuan pembelajaran hari ini dan langkah-langkah kegiatannya. Sementara itu, kegiatan inti (45 menit) diisi dengan 1) siswa diberi pengarahan tentang permainan menggunakan media terhadap materi; 2) Guru membagi kelompok yang terdiri dari 5 anakl; 3) semua siswa menyanyikan lagu "Matahari Terbenam" sambil membawa media alat kecil (pensil) diberikan pada temannya secara beurutan.Jika guru menyuruh berhenti bernyanyi maka anak yang memegang pensil terakhir dapat maju ke depan untuk mengambil kartu yang ada pada kotak ajaib; 4) Anak yang mendapat kesempatan mengambil kartu,kemudian membuka isi kartu dan menjawabnya.Isi kartu tidak hanya berisi soal,tapi juga dourprise,dan jawaban benar anak mendapat bintang; 5) Bagi anak yang mengumpulkan bintang dengan jumlah banyak akan mendapat reword/hadiah; 6) Kegiatan dilanjutkan secara bergantian tiap-tiap anggota kelompok; 7) guru mempresentasikan hasil kegiatan. Kemudian kegiatan Penutup (10 menit) dilakukan aktivitas 1) siswa bersama dengan guru membuat kesimpulan; 2) guru membagikan soal evaluasi kepada masing-masing siswa, siswa mengerjakan secara individu tentang materi pembelajaran hari ini; 3) Guru melakukan refleksi terhadap pembelajaran yang baru dilakukan; 4) guru memberi kesempatan bertanya pada siswa tentang hal yang kurang jelas; 5) Guru mengkhiri pelajaran dengan bedoa bersama.

\section{c. Pengamatan (observasi)}

Pengamatan kegiatan pembelajaran dilakukan oleh kolaborator. Adapun pengamatannya meliputi : Pengamatan guru pada saat pelaksanaan Kegiatan Belajar Mengajar (KBM) dan pengamatan kegiatan siswa pada saat KBM. Adapun hasil pengamatan guru saat Kegiatan Belajar Mengajar menunjukan bahwa guru sudah melaksanakan kegiatan pembelajaran, mulai dari pendahuluan,inti dan penutup walaupun belum 100\%, yaitu (13/15) x 100\% = 87\%. Adapun pengamatan terhadap siswa saat Kegiatan Belajar Mengajar (KBM) berdasar data hasil pengamatan saat Kegiatan Belajar Mengajar (KBM) pada siklus I keaktifan kreteria 
3 mencapai 40\%, kreteria 2 mencapai 35\%, kreteria 1 mencapai 25\% sedangkan untuk aspek kerjasaman kreteria 3 mencapai $35 \%$, kreteria 2 mencapai $45 \%$ dan kreteria 1 mencapai $20 \%$. Atau secara keseluruhan keaktifan siswa mencapai $71,67 \%$. Hal ini menunjukan masih perlunya diadakan perbaikan dalam pelaksanaan pada siklus berikutnya walaupun sebenarnya sudak cukup baik. Pada kegiatan penutup Kegiatan Belajar Mengajar guru memberikan evaluasi secara tertulis untuk mengetahui tingkat pemahaman siswa terhadap materi pelajaran hari ini. Hasil evaluasi atau penilaian Siklus I pada Tabel 1 sebagai berikut:

Tabel 1. Hasi Penilaian Tes Tulis Siklus I

\begin{tabular}{|c|c|c|c|}
\hline No & Nilai & Frekuensi & Persentase \\
\hline 1 & $90-100$ & - & - \\
\hline 2 & $70-89$ & 14 & 70,00 \\
\hline 3 & $50-69$ & 6 & 30,00 \\
\hline 4 & $30-49$ & - & - \\
\hline \multicolumn{2}{|c|}{ Jumlah } & 20 & 100,00 \\
\hline
\end{tabular}

Dari hasil penilaian yang dilaksanakan setelah siklus I ada dua kategori .Adapun tingkat penguasaan siswa dapat dirinci seperti berikuta: 1) Siswa dengan tingkat penguasaan 70-80 sebanyak 14 anak (70\%), 2) Siswa dengan tingkat penguasaan 50-60 ada 6 anak (30\%). Dari paparan data penguasaan materi Berbagai Sumber Energi menggunakan media kabib tampak yang memiliki tingkat penguasaan materi di sama atau diatas KKM (70) ada 14 anak (70\%). Hal ini menunjukkan penguasaan materi sudah meningkat dibandingkan sebelum didakan tindakan namun secara klasikal penguasaan materi belum terpenuhi. Persentase ketuntasan hasil penilian Siklus I tetera pada Tabel 2 berikut ini

Tabel 2. Ketuntasan Belajar Siklus I

\begin{tabular}{|c|c|c|c|c|c|}
\hline No & Nilai $(\mathrm{N})$ & Frekuensi & $\mathrm{NxF}$ & Persentase & Keterangan \\
\hline 1 & 55,00 & 1 & 55,00 & 5 & Tidak Tuntas \\
\hline 2 & 60 & 5 & 300,00 & 25 & Tidak Tuntas \\
\hline 3 & 65 & - & - & - & - \\
\hline 4 & 70 & 7 & 490,00 & 35 & Tuntas \\
\hline 5 & 75 & 4 & 300,00 & 20 & Tuntas \\
\hline 6 & 80 & 3 & 240,00 & 15 & Tuntas \\
\hline \multirow{2}{*}{\multicolumn{3}{|c|}{$\frac{\text { Jumlah }}{\text { Rata-rata }}$}} & 1.385 & 100,00 & \\
\hline & & & 69,25 & & \\
\hline
\end{tabular}

Berdasar Tabel 2 diketahui bahwa siswa yang telah tuntas memperoleh nilai sama dengan atau lebih besar dari pada 70 dalam Siklus I sebanyak 14 siswa (70). Persentase ketuntasan belum mencapai kreteria yang ditentukan sebesar $80 \%$. Rata-rata nilai Siklus I sebesar 69,25

\section{d. Refkleksi}

Berdasarkan hasil diskusi bersama kolaborator dan hasil evaluasi yang dilakukan dapat disimpulkan sebagai berikut:

a. Skenario pembelajaran dapat berlangsung sesuai dengan yang diharapkan dan dapat digunakan siklus berikutnya dengan memvariasi pembelajaran menggunakan media KABIB (Kartu Belajar Ajaib).

b. Kegiatan pembelajaran belum maksimal masih ada siswa yang kurang aktif dalam menjawab pertanyaan, sehingga perlu adanya motivasi.

c. Pada saat teman mendapatkan hadiah hasil permainan, masih ada anak yang ingin mendapatkan lagi. 
Guru selaku peneliti menjalankan pembelajaran berdasarkan rencana pelaksanaan pembelajaran (RPP). Guru juga senantiasa memfasilitasi pembelajaran siswa dengan berkeliling dari kelompok ke kelompok sambil menanyakan kesulitan yang dialami oleh masing-masing anggota kelompok. Pada saat siswa maju ke depan untuk mengambil kartu ,masih ada anak yang takut untuk menghindar agar tidak maju.Karena anak tersebut merasa tidak mampu untuk menjawab soal.Disebabkan kurang menguasai materi yang harus disampaikan. Prestasi belajar siswa pada Siklus 1 ini kurang, karena belum mencapai ketuntasan minimal secara klasikal.Siswa yang tuntas belajar sebanyak 14 anak (70\%).Ketuntasan belum mencapai minimal $75 \%$.Rata-rata nilai 69.25 dan belum mencapai KKM. Penyebab utama kekurang berhasilan tersebut adalah penggunaan media KABIB ynag kurang dipakai, dan siswa kurang aktif kadang dia masih mengandalkan temannya yang dianggap bisa, oleh karena itu pelaksanaan pembelajaran perlu ditingkatkan dan media KABIB perlu di variasi sehingga nantinya akan terwujud pembelajaran yang aktif, kreatif, efektif dan menyenangkan. Dengan demikian penelitian ini perlu dilanjutkan ke Siklus 2, sehingga prestasi siswa bisa meningkat maksimal.

Siklus II

\section{a. Perencanaan}

Perencanaan penelitian Tindakan kelas Siklus II, ini dilaksanakan di SDN 1 Karangam selama dua pertemuan yaitu pada tanggal 25 dan 26 September 2018.Kegiatan pada tahap ini meliputi; mempersiapkan rencana pembelajaran dengan materi manfaat berbagai sumber energi.Berdasarkan pengamatan saat pembelajaran pada Siklus I belum maksimal karena masih ada anak yang kurang semangat karena takut tidak bisa menjawab soal,untuk itu diharapkan pada siklus II saat kegiatan siswa semuanya lebih aktif. Untuk meningkatkan motivasi belajar siswa, pada Siklus II ini siswa diminta untuk lebih semangat dan memperhatikan penjelasan materi.Hal ini dilakukan guru agar semua anak aktif tidak ada yang Cuma diam dan mengandalakan teman yang bisa. Selain itu diberikan penghargaan kepada anak yang berprestasi, yaitu aktif dalam kegiatan pembelajaran dan dalam mempresentasikan hasil diskusi diambil terbaik 1, 2 dan 3 diumumkan.

b. Pelaksanaan

Siklus II dilaksanakan selama dua pertemuan yaitu pada tanggal 25 dan 26 September 2018 pada pukul 07.00 sampai 09.00 WIB. Dengan langkah-langkah sebagai berikut:

Pendahuluan (10 menit)

1. Mengucapkan salam pembuka serta meminta salah satu siswa memimpin pembacaan doa.

2. Guru mengabsen kehadiran siswa

3. Guru melakukan apersepsi dengan mengajak menyanyikan lagu macammacam sumber energi.

4. Guru menyampaikan tujuan pembelajaran hari ini dan langkah-langkah kegiatannya

Kegiatan Inti (45 menit)

1. Guru membagi siswa menjadi 5 kelompok masing -masing kelompok 4 orang.

2. Tiap anggota dalam kelompok semangat untuk menerima tongkat kecil dan maju ke depan mengambil kartu.

3. Tiap anggota kelompok diajak bernyanyi sambil memberikan tongkat kecil kepada temannya dalam satu kelompok secara berurutan ,dan berhenti saat lagu dihentikan.

4. Anggota dari kelompok lain melakukan kegiatan seperti kelompok sebelumnya. 
5. Setelah selesai sampai kelompok terakhir,guru menghitung jumlah skor dari hasil jawaban tiap anggota kelompok.

6. Guru memberikan penghargaan kepada kelompok yang mendapat skor terbanyak,dengan cara diumumkan di depan kelas, diambil tiga besar.

7. Pembahasan hasil kegiatan pembelajaran dengan media Kabib.

Penutup (15 menit)

1. Siswa membuat kesimpulan bersama dengan guru membuat kesimpulan

2. Guru memberi kesempatan bertanya pada siswa tentang hal yang kurang jelas

3. Soal evaluasi dibagikan kepada siswa, selanjutnya dapat dikerjakan secara individu oleh para siswa tentang materi pembelajaran hari ini

4. Dilakukan suatu refleksi oleh guru terhadap pembelajaran yang dilakukan

5. Guru memberikan tugas rumah untuk membaca buku siswa halaman 59 sampai 65

6. Guru mengakhiri pembelajaran dengan mengucap salam

c. Pengamatan

Pengamatan terhadap pelaksanaan kegiatan pembelajaran dilakukan oleh kolaborator. Adapun pengamatannya meliputi: Pengamatan guru pada saat pelaksanaan Kegiatan Belajar Mengajar (KBM) dan pengamatan kegiatan siswa pada saat KBM. Adapun hasil pengamatan guru saat Kegiatan Belajar Mengajar Pelaksanaan pada siklus II sudah sesuai dengan perencanaan Sedangkan pengamatan terhadap siswa saat KBM pada siklus II keaktifan siswa mengalami peningkatan dengan adanya perlakuan yang diberikan oleh guru dengan menunjuk siswa untuk maju ke depan dan menjawab pertanyaan-pertanyaan .Yaitu kreteria 3 mencapai 65\%, kreteri 2 mencapai 30\%, kreteria 1 mencapai 10\% sedangkan untuk aspek kerjasaman kreteria 3 mencapai $55 \%$, kreteria 2 mencapai $35 \%$ dan kreteria 1 mencapai $10 \%$.atau secara menyeluruh mencapai $84 \%$. Hal ini menunjukan adanya peningkatan keaktifan siswa setelah guru meminta siswa untuk semangat dan berani menjawab. Dan guru wakil kelompok yang akan mempresentasikan hasil kegiatan pembelajaran materi manfaat sumber-sumber energi di depan kelas.

Pada kegiatan penutup guru memberikan evaluasi secara tertulis untuk mengetahui tingkat pemahaman siswa terhadap materi pelajaran hari ini.

Tabel 3 Hasi Penilaian Tes Tulis pada Siklus II

\begin{tabular}{|c|c|c|c|}
\hline No & Nilai & Frekuensi & Persentase \\
\hline 1 & $90-100$ & 2 & 10 \\
\hline 2 & $70-89$ & 15 & 75 \\
\hline 3 & $50-69$ & 3 & 15 \\
\hline 4 & $30-49$ & - & - \\
\hline \multicolumn{2}{|c|}{ Jumlah } & 20 & 100,00 \\
\hline
\end{tabular}

Dari hasil penilaian yang dilaksanakan setelah siklus II ada tiga kategori yaitu: 1) Siswa dengan tingkat penguasaan 90-100 sebanyak 2 anak $(10,00)$, 2)Siswa dengan tingkat penguasaan 70-89 sebanyak 15 anak $(75,00), 3)$ Siswa dengan tingkat penguasaan 50-69 sebanyak 3 anak (15,00).Dari paparan data penguasaan materi penyakit yang menyerang alat pernapasan manusia tampak memiliki tingkat penguasaan materi sama atau diatas KKM (70) sebanyak 17 anak (85\%). Hal ini menujukkan bahwa penguasaan materi pada Siklus II telah mencapai indikator.

Adapun persentase ketuntasan hasil penilaian pada Siklus II dapat dipaparkan pada Tabel 4 berikut ini 
Tabel 4. Ketuntasan Penilaian Siklus II

\begin{tabular}{|c|c|c|c|c|c|}
\hline No & Nilai $(\mathrm{N})$ & Frekuensi (F) & $\mathrm{NxF}$ & Persentase & Keterangan \\
\hline 1 & 60 & 1 & 60,00 & 5 & Tidak Tuntas \\
\hline 2 & 65 & 2 & 130,00 & 10 & Tidak Tuntas \\
\hline 3 & 70 & - & - & - & - \\
\hline 4 & 75 & 4 & 300,00 & 20 & Tuntas \\
\hline 5 & 80 & 1 & 80,00 & 5 & Tuntas \\
\hline 6 & 85 & 10 & 850,00 & 50 & Tuntas \\
\hline 7 & 90 & 1 & 90,00 & 5 & Tuntas \\
\hline 8 & 95 & 1 & 95,00 & 5 & Tuntas \\
\hline \multirow{2}{*}{\multicolumn{3}{|c|}{\begin{tabular}{r|} 
Jumlah \\
Rata-rata
\end{tabular}}} & 1.605 & 100,00 & \\
\hline & & & 80,25 & & \\
\hline
\end{tabular}

Berdasarkan Tabel 4 diketahui bahwa siswa yang telah tuntas memperoleh nilai sama atau diatas KKM (70) dalam Siklus II sebanyak 17 anak (85\%). Persentase ketuntasan telah mencapai kreteria yang telah ditentukan sebesar $80 \%$.Nilai ratarata pada Siklus II sebesar 80,25 dan telah mencapai KKM (70).

\section{d. Refleksi}

Berdasarkan hasil diskusi bersama kolaborator dan hasil evaluasi (tes tulis) dapat disimpulkan sebagai berikut:

1. Skenario pembelajaran berlangsung sesuai dengan yang direncanakan (diharapkan).

2. Dalam kegiatan pembelajaran siswa terlihat bersungguh-sungguh dan lebih aktif dan lebih semangat.

3. Siswa yang tuntas secara individu ada 17 anak (85\%) hal ini menunjukkan ketuntasan klasikal sudah tercapai.

4. Situasi belajar yang diciptakan guru aktif, kreatif dan menyenangkan.Hal ini ditunjukkan dengan nilai rata-rata.

Berdasarkan uraian yang telah dijabarkan, siklus II pembelajaran materi manfaat sumber-sumber energi menggunakan media Kabib(Kartu Belajar Ajaib) sudah berjalan dengan baik, hal ini sudah ditandai:

1. Melalui penelitian ini, media KABIB memiliki dampak positif dalam meningkatkan prestasi belajar siswa. Hal ini dapat dilihat dari semakin tingginya tingkat pemahaman siswa terhadap materi yang diberikan oleh guru. Ketuntasan balajar juga mengalami peningkatan dari siklus I sebesar 70,00 menjadi $85,00 \%$ pada Siklus II.

2. Kecakapan guru dalam manajemen belajar mengajar. Analisa data menunjukkan bahwa terdapat aktifitas guru yang selama pembelajaran telah melaksanakan langkah-langkah belajar dengan baik menggunakan pembelajaran jigsaw, terlihat dari aktifitas membimbing dan mengamati siswa dalam mengerjakan Lembar diskusi, menemukan konsep, menjelaskan, memberi umpan balik/evaluasi/tanya jawab. Guru dalam proses pembelajaran mengalami peningkatan pada Siklus I mencapai $87 \%$ sedangkan Siklus II menjadi $100 \%$. Hasil ini berdampak positif terhadap prestasi belajar siswa, dengan meningkatnya nilai rata-rata siswa pada setiap siklus, dari rata-rata Siklus I sebesar 69.25 menjadi 80 pada Siklus II.

3. Aktifitas siswa dalam pembelajaran. Analisis data menunjukkan dengan menerapkan media KABIB, aktifitas siswa dalam proses pembelajaran IPA pada materi "berbagai sumber energi" dikatakan sebagai aktifitas siswa berkategori aktif, yaitu $72 \%$ pada Siklus I menjadi $84 \%$ pada Siklus II, ditandai 
juga dengan siswa mampu menjawab soal-soal sesuai dengan isi kartu yang diperoleh.

Keberhasilan pembelajaran materi berbagai sumber energi dengan media kabib sudah baik. Keberhasilan siswa didasarkan pada hasil pengamatan terhadap proses pembelajaran yang berkenaan dengan kegiatan guru maupun kegiatan siswa dalam pembelajaran. Disamping itu juga dapat diketahui dari peningkatan hasil evaluasi yang dapat diketahui dengan cara membandingkan hasil nilai evaluasi siswa pada Pra Siklus, Siklus I dan Siklus II dapat dilihat pada Tabel 5 berikut ini:

Tabel 5. Perbandingan Hasil Evaluasi Pada Pra Siklus, Siklus I dan Siklus II

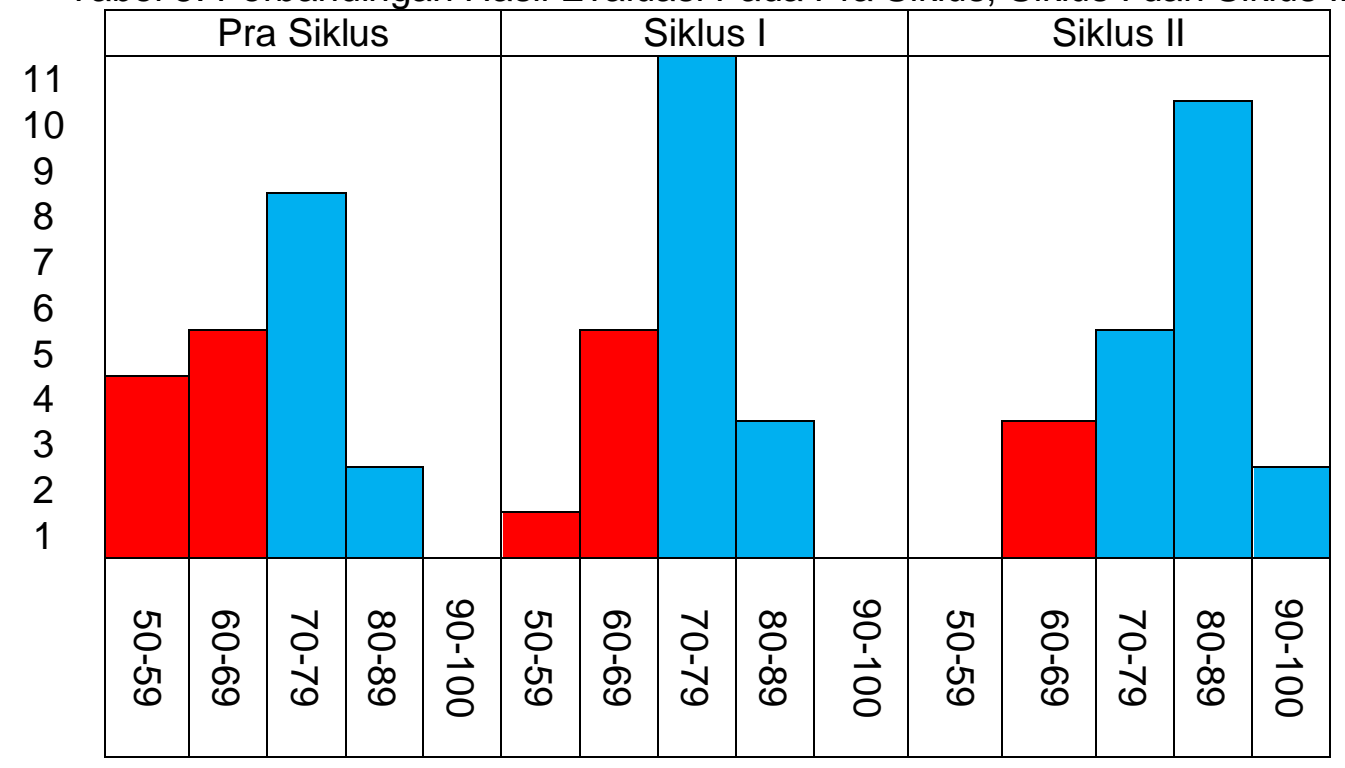

Tabel 5 menunjukan bahwa pada Pra Siklus siswa yang mendapat nilai di bawah KKM sebanyak 9 anak, pada Siklus I sebanyak 6 anak sedangkan pada Siklus II sebanyak 3 anak. Pada Pra Siklus anak yang mendapat nilai sama atau di atas KKM (70) sebanyak 11 anak (55 \%), Siklus I sebanyak 14 anak (70\%) dan pada Siklus II sebanyak 17 anak (85\%). Berdasarkan data tersebut disimpulkan bahwa Prestasi belajar Berbagai Sumber Energi dari Pra Siklus ke Siklus I meningkat sebesar $15 \%$, Siklus I ke Siklus II meningkat sebesar $15 \%$. Adapun nilai rata-rata Pra Siklus sebesar 66, Siklus I sebesar 69,25 dan Siklus II 80. Pra Siklus ke Siklus I meningkat 3,25 dan pada Siklus I ke siklus II meningkat sebesar 10,75. Peningkatan ketuntasan belajar Berbagai Sumber Energi dapat diketahui dengan cara membandingkan ketuntasan Pra Siklus, Siklus I dan Siklus II.

Tabel 6. Perbandingan Ketuntasan Belajar Identifikasi Alat Pernapasan Manusia Pra Siklus, Siklus I dan Siklus II

\begin{tabular}{|c|c|c|c|}
\hline & Pra Siklus & Siklus I & \multicolumn{2}{|c|}{ Siklus II } \\
\hline 17 & & & \\
16 & & & \\
15 & & & \\
14 & & & \\
13 & & & \\
12 & & & \\
11 & & & \\
10 & & & \\
9 & & & \\
\hline
\end{tabular}




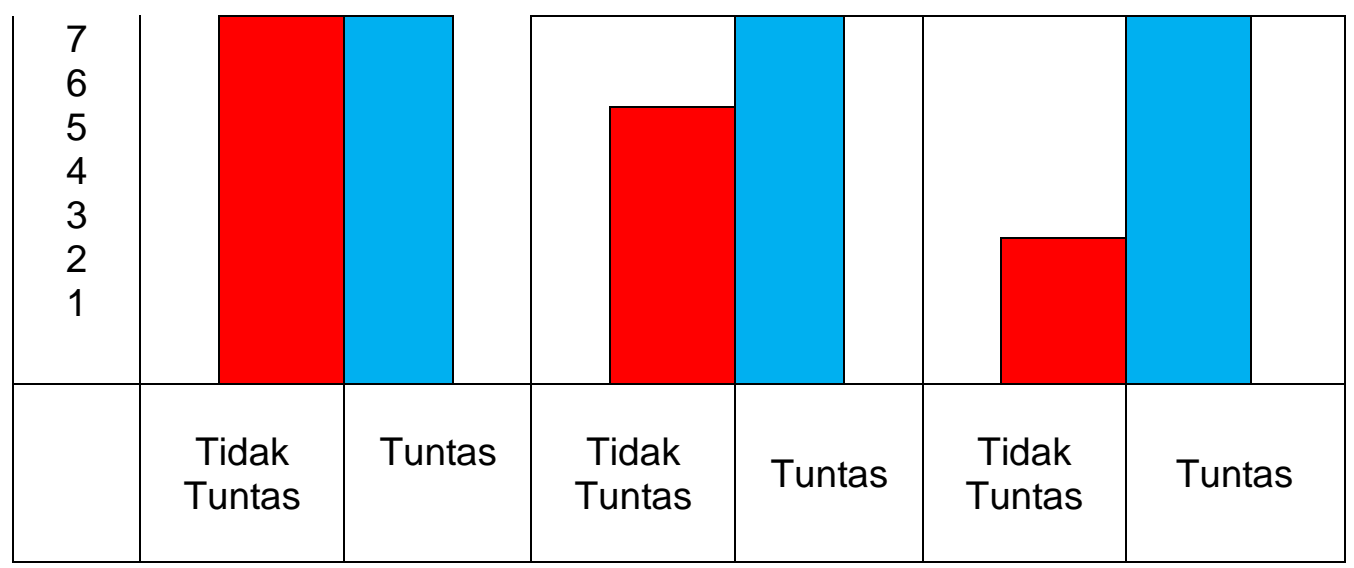

Tabel 6 menunjukkan bahwa pada Pra Siklus siswa yang telah tuntas mencapai nilai di atas KKM (70) sebanyak 11 anak (55\%), pada Siklus I sebanyak 14 anak (70\%) meningkat $15 \%$ dan pada Siklus II sebanyak 17 anak (85\%) dari Siklus I ke Siklus II ketuntasan meningkat sebanyak 15\%, Ketuntasan belajar telah tercapai. Peningkatan nilai dan ketuntasan belajar siswa ini menunjukkan bahwa model pembelajaran penggunaan Media KABIB (Kartu Belajar Ajaib) bsia membawa perubahan proses pembelajaran yang tadinya berpusat pada guru menjadi proses pembelajaran yang berpusat pada siswa. Ditambah dalam proses pembelajaran siswa lebih meningkat. Perbandingan ketuntasan tersebut dapat dilihat pada Tabel 6 berikut ini.

\section{KESIMPULAN}

Hasil evaluasi pada Siklus I ditunjukkan oleh penguasaan siswa terhadap Berbagai Sumber Energi sudah ada peningkatan dibandingkan dengan pra siklus ratarata $66(55 \%)$ namun belum maksimal, karena siswa yang tuntas belajar dengan nilai sama atau lebih besar dari KKM (70) sebanyak 14 anak (70\%) dengan rata-rata nilai 69,25 . Sedangkan hasil penilaian pada Siklus II menunjukan bahwa penguasaan siswa terhadap Materi Berbagai Sumber Energi sudah sangat baik terbukti siswa yang tuntas belajar dengan mendapatkan nilai sama atau lebih besar dari KKM (70) sebanyak 17 anak $(85 \%)$ dengan nilai rata-rata 80 .

$\mathrm{Hal}$ ini menunjukkan bahwa pembelajaran menggunakan media KABIB (Kartu Belajar Ajaib ) dapat meningkatkan prestasi belajar IPA materi Berbagai Sumber Energi Siswa kelas IV semester 1 tahun pelajaran 2017-2018 SDN 1 Karangan Kecamatan Karangan Kabupaten Trenggalek.

\section{DAFTAR RUJUKAN}

Arikunto, Suharsimi. 2011. Prosedur Penelitian: Suatu Pendekatan Praktik. Edisi. Revisi VII. Jakarta: PT. Rineka Cipta.

B. Uno, Hamzah. 2008. Teori Motivasi dan Pengukurannya, Jakarta : Bumi. Aksara. Huda, Miftahul. 2011. Cooperative Learning. (Yogyakarta: Pustaka Belajar).

Jauhan,A. dan Elisah,T. (2011) Implementasi Pendidikan Karakter dalam Pembelajaran. Jakarta : Prestasi Pustaka

Made Wena. (2009). Strategi Pembelajaran Inovatif Kontemporer. Jakarta: Bumi. Aksara.

Moleong, Lexy. (2002). Metodologi Penelitian Kualitatif. Bandung: PT. remaja Rosdakarya

Nana Sudjana. (2002). Penilaian Hasil Proses Belajar Mengajar. Bandung: Remaja Rosdakarya.

Prawiradilaga, Dewi Salma dan Eveline Siregar. 2008. Prinsip Disain. Pembelajaran. Jakarta: Kencana

Rusman. 2010. Model Model Pembelajaran. Bandung: Rajawali Pers,

Slavin, R. E. (2010). Cooperative Learning Teori, Riset dan Praktik. Bandung: Nusa Media. 